\title{
Solar Energy Development Assistance for Fort Hunter Liggett
}

\author{
BJ Russo \\ MG Hoffman \\ WD Chvala, Jr.
}

March 2011

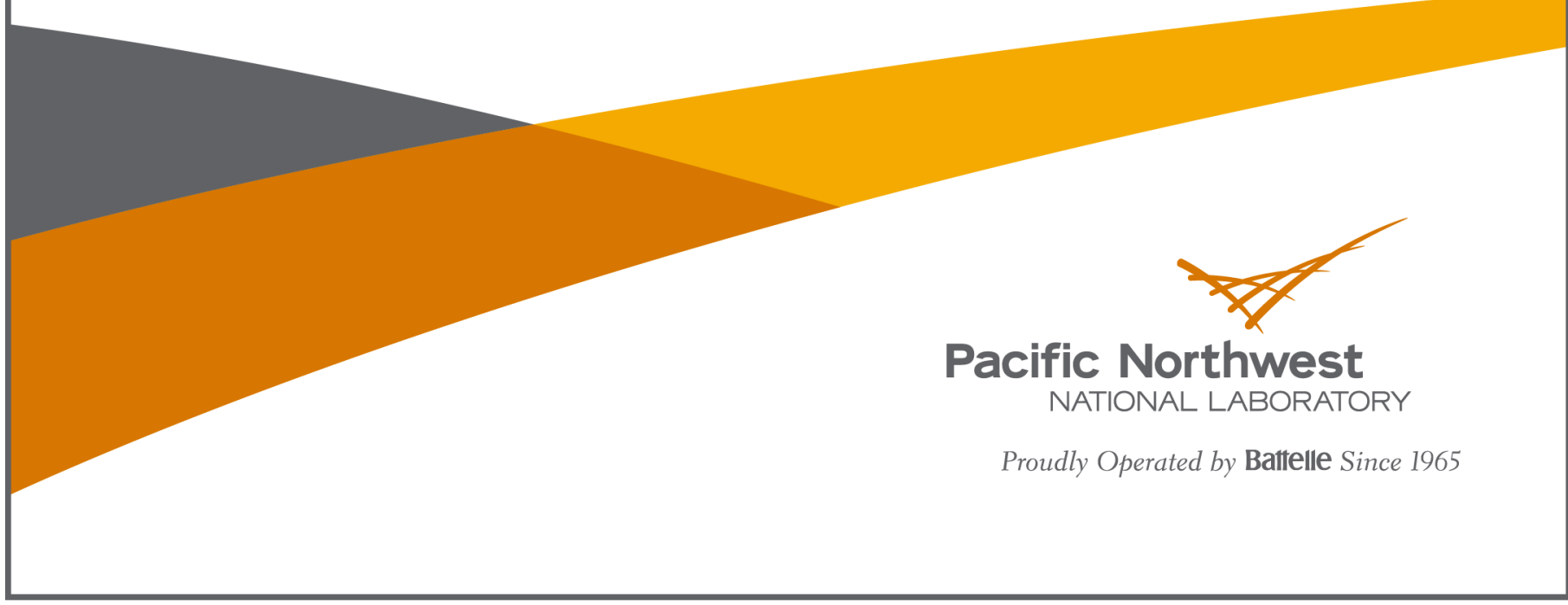




\title{
DISCLAIMER
}

This report was prepared as an account of work sponsored by an agency of the United States Government. Neither the United States Government nor any agency thereof, nor Battelle Memorial Institute, nor any of their employees, makes any warranty, express or implied, or assumes any legal liability or responsibility for the accuracy, completeness, or usefulness of any information, apparatus, product, or process disclosed, or represents that its use would not infringe privately owned rights. Reference herein to any specific commercial product, process, or service by trade name, trademark, manufacturer, or otherwise does not necessarily constitute or imply its endorsement, recommendation, or favoring by the United States Government or any agency thereof, or Battelle Memorial Institute. The views and opinions of authors expressed herein do not necessarily state or reflect those of the United States Government or any agency thereof.

\author{
PACIFIC NORTHWEST NATIONAL LABORATORY \\ operated by \\ BATTELLE \\ for the \\ UNITED STATES DEPARTMENT OF ENERGY \\ under Contract DE-AC05-76RL01830 \\ Printed in the United States of America \\ Available to DOE and DOE contractors from the \\ Office of Scientific and Technical Information, \\ P.O. Box 62, Oak Ridge, TN 37831-0062; \\ ph: (865) 576-8401 \\ fax: $(865) 576-5728$ \\ email: reports@adonis.osti.gov

\begin{abstract}
Available to the public from the National Technical Information Service, U.S. Department of Commerce, 5285 Port Royal Rd., Springfield, VA 22161 ph: (800) 553-6847 fax: (703) 605-6900 email: orders@ntis.fedworld.gov online ordering: http://www.ntis.gov/ordering.htm
\end{abstract}


PNNL-20290

\section{Solar Energy Development Assistance for Fort Hunter Liggett}

BJ Russo

MG Hoffman

WD Chvala, Jr.

March 2011

Prepared for

U.S. Army Deputy Assistant Secretary of the Army (DASA) and the U.S. Army Engineering and Support Center, Huntsville, AL

under Contract DE-AC05-76RL01830

Pacific Northwest National Laboratory

Richland, Washington 99352 



\section{Executive Summary}

Increasing use of renewable energy is mandated by several executive orders and legislation. Fort Hunter Liggett has many attributes that enhance its suitability for renewable energy development. First, the site is located south of San Francisco in a remote portion of the coastal foothills. Brush and forest fires are frequent and often cause power outages, which subsequently impacts the site's training mission. In addition, the site's blended electric rate during fiscal year (FY) 2010 was high at $12 \not / \mathrm{kWh}$. Lastly, the site has a moderately high solar resource of nearly $5.7 \mathrm{kWh} / \mathrm{m}^{2} /$ day on a south facing, latitude-tilted surface.

In light of these factors, the site is a clear candidate for a solar photovoltaic array. Prior to Pacific Northwest National Laboratory's (PNNL) involvement, the site secured funding for a 1megawatt (MW) photovoltaic (PV) array. To best implement this project, PNNL conducted a site visit and was tasked with providing the site technical guidance and support regarding module selection, array siting, and other ancillary issues.

Although Fort Hunter Liggett is a relatively large site, much of its territory is hilly and reserved for training. Moreover, the cantonment area is relatively small and is confined to a large valley. Unfortunately, much of this valley is within a floodplain and construction on the remaining open land is complicated by the presence of endangered species and two historical structures. Consequently, array siting will be challenging. During the site visit, PNNL reviewed several promising locations for a PV array including the large vehicle storage area and several open fields near the existing electrical distribution lines and primary substation. PNNL concluded that although the open fields are simpler proposed sites that would minimize construction costs, the environmental constraints and historical preservation concerns will likely dominate the siting decision. Consequently, the vehicle storage area will likely be the most practical location for array installation.

Beyond possible siting locations, the site also requested guidance on PV module selection and information on the environmental attributes of common module types. PNNL provided the site a summary of common module types including monocrystalline silicon, polycrystalline silicon, amorphous silicon, cadmium telluride, and copper indium gallium selenide cells. In addition, PNNL described the environmental attributes and possible concerns for each major technology. In general, PV materials are relatively benign. The principal concern for the considered modules is the presence of the heavy metal cadmium in cadmium telluride cells. However, the concentration of cadmium is minimal and does not pose an issue during operation of the array. Nevertheless, care must be taken during the disposal of these cells to assure proper processing. 


\section{Table of Contents}

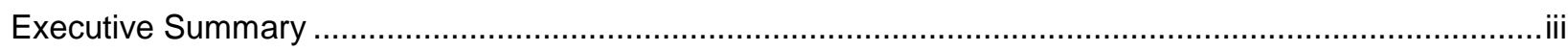

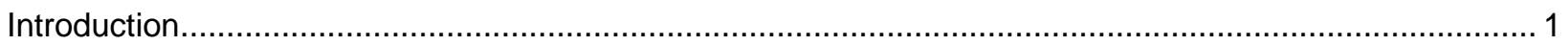

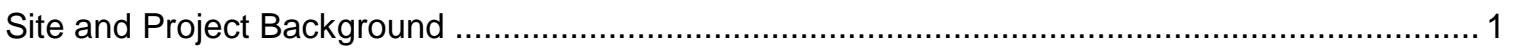

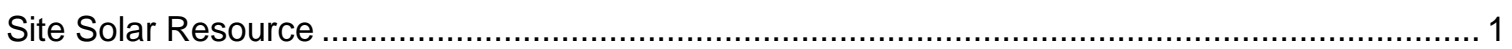

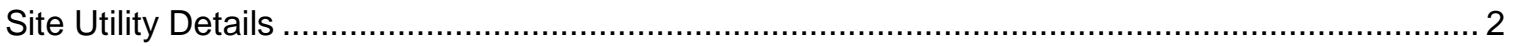

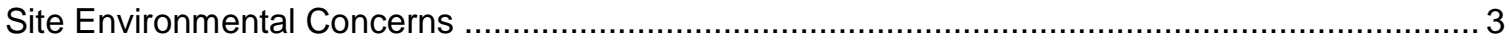

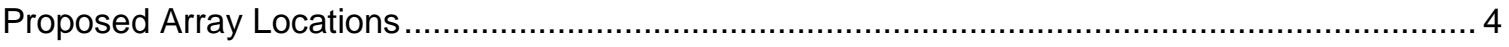

Proposed Photovoltaic Technologies to Consider ................................................................ 9

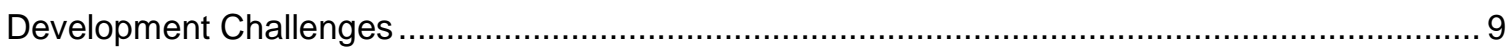

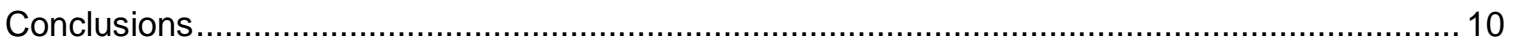

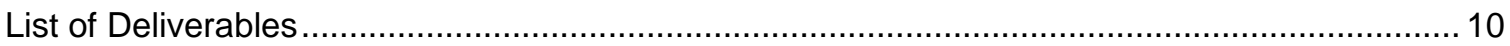

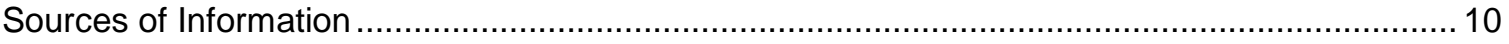

Appendix A: Detailed Description of Potential Array Locations ........................................................ 1

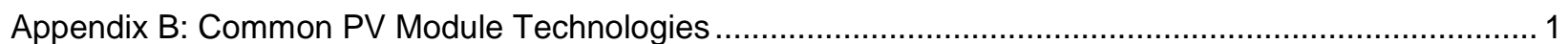




\section{Figures}

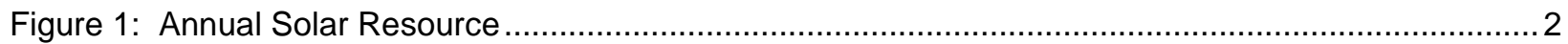

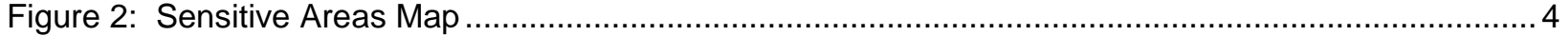

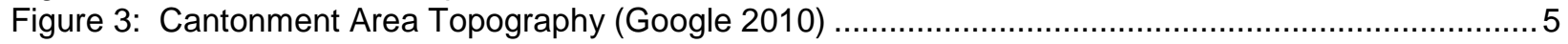

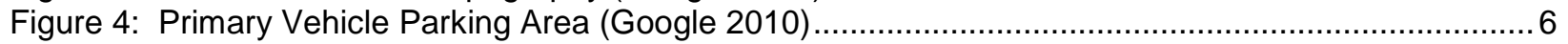

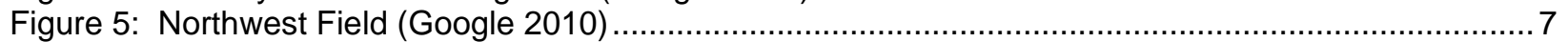

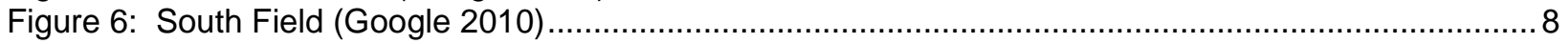

Figure A-1: Vehicle Storage Area (the area in red indicates future expansion) (Google 2010) ..................2

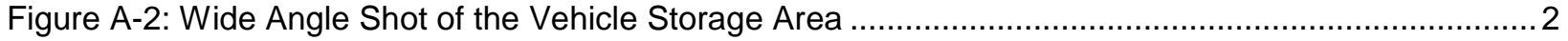

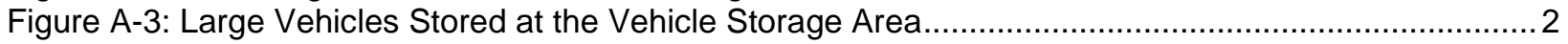

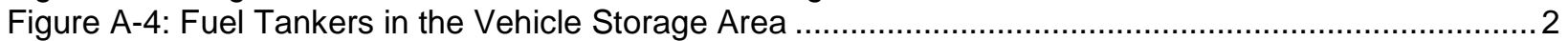

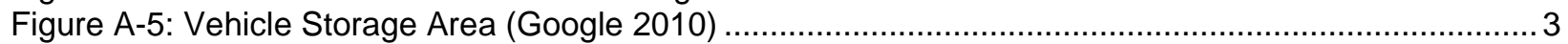

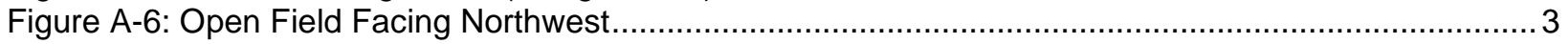

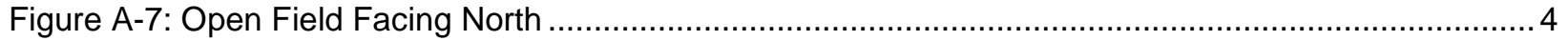

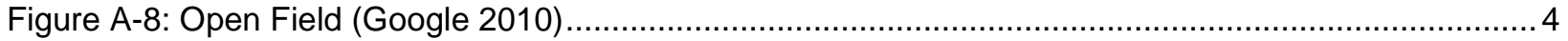

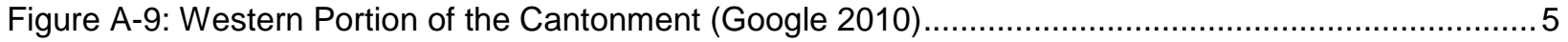

Figure A-10: Open Area SW of Sulphur Springs \& Del Venturi (Google 2010) ...................................6

Tables

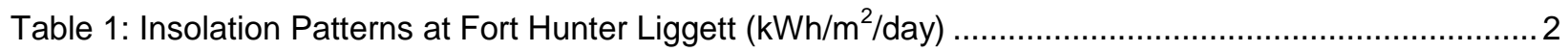




\section{Introduction}

Pacific Northwest National Laboratory (PNNL) was asked to provide Fort Hunter Liggett with technical guidance and support in specifying and planning the installation of a 1-megawatt (MW) photovoltaic (PV) array. The site also requested support in determining the feasibility and practicality of creating a microgrid for the array.

\section{Site and Project Background}

Established in the 1940s, Fort Hunter Liggett, which is located in the coastal foothills of central California, is the largest Army Reserve installation and the eighth largest site in the Army. The principal mission of the site is to provide training for combat support and combat service support. The site is remote, has a moderately high solar resource, purchases expensive electricity, and experiences frequent outages. These conditions are all beneficial for PV development.

Prior to PNNL's involvement, Fort Hunter Liggett secured \$10 million in funding for a 1-MW PV solar array in 2010. In addition to designing and constructing the array, Fort Hunter Liggett is interested in establishing an array operations and maintenance (O\&M) contract for the lifetime of the array. O\&M for an array of this type would typically include panel washing, monitoring, inverter replacement, wire connection inspections, and controls replacement as necessary. O\&M costs for this array may be higher than average because of the hybrid array-shading structure arrangement.

Fort Hunter Liggett has also expressed interest in expanding this array to 2- or 3-MW in the future. At this size, the system will produce power in excess of the site's demand, and Fort Hunter Liggett will need to export their electricity to the grid. Although California's net metering laws require the site's utility to net meter facilities up to 1-MW, the site will need to closely coordinate with their utility if the site wishes to pursue the array expansion. If Fort Hunter Liggett is interested in large scale distributed generation, it will need to comply with California's Rule 21 . However, this may also open the site to large stand by charges for its utility service. Any subsequent economic analysis for additional PV capacity should account for this factor.

In addition to constructing an array, there is also interest in establishing a microgrid for enhanced energy security and reliability. According to site personnel, the Fort frequently encounters electrical outages (as many as 20 per year) because of regional brush and forest fires. Outages can be as short as half an hour, or as long as 6 or more hours. Prolonged outages cause training sessions to cease, which impacts training quality, training budgets, and the site's overall mission.

\section{Site Solar Resource}

Insolation is often expressed in units of $\mathrm{kWh} / \mathrm{m}^{2} /$ day or as irradiance, which has units of watts $/ \mathrm{m}^{2}$. Insolation is energy that can be converted to electricity or thermal energy. When describing insolation, it is critical to note the orientation of the solar energy collector (e.g., a PV module, a solar hot water panel, etc.). While there is no default collector orientation for reporting insolation values, the two most common orientations are flat (sometimes called horizontal) and latitude-tilted, south facing. A flat-mounted collector is placed flat on unsloped ground or on a flat roof. A latitude-tilted, south facing collector faces perfectly south and is tilted at an angle 
equal to the site's latitude. This orientation helps optimize solar energy collection because the collector receives more insolation than if the collector lays flat on the ground or at another angle. Occasionally it is useful to express insolation for surfaces that track the sun along one or two axes. These tracking systems are capable of absorbing more sunlight than fixed systems because the modules rotate to face the sun as it travels across the sky.

In the U.S., insolation ranges from $3 \mathrm{kWh} / \mathrm{m}^{2} /$ day in Alaska to well over $7 \mathrm{kWh} / \mathrm{m}^{2} /$ day in the southwest for a south facing, latitude-tilted collector. Consequently, solar energy systems are technically feasible across all of the U.S. Table 1 displays the average insolation at Fort Hunter Liggett for three different panel orientations: tilt 0 (e.g., a flat roof), tilt 36 (latitude tilt), and a single-axis tracking system.

Table 1: Insolation Patterns at Fort Hunter Liggett ( $\left.\mathrm{kWh} / \mathrm{m}^{2} / \mathrm{day}\right)$ (NASA 2010)

\begin{tabular}{|c|c|c|c|c|c|c|c|c|c|c|c|c|c|}
\hline & Jan & Feb & Mar & Apr & May & Jun & Jul & Aug & Sep & Oct & Nov & Dec & $\begin{array}{c}\text { Annual } \\
\text { Average }\end{array}$ \\
\hline Tilt 0 & 2.26 & 3.03 & 4.11 & 5.17 & 5.81 & 6.25 & 5.98 & 5.44 & 4.52 & 3.52 & 2.49 & 2.01 & 4.22 \\
\hline Tilt 36 & 3.42 & 4.49 & 5.44 & 6.31 & 6.77 & 7.00 & 7.08 & 7.07 & 6.70 & 5.90 & 4.32 & 3.30 & 5.65 \\
\hline Single-Axis Tracking & 4.04 & 5.38 & 6.93 & 8.18 & 9.26 & 9.72 & 9.89 & 9.84 & 8.90 & 7.75 & 5.21 & 3.90 & 7.42 \\
\hline
\end{tabular}

Figure 1 displays this data graphically. Naturally, the insolation peaks in the summer.

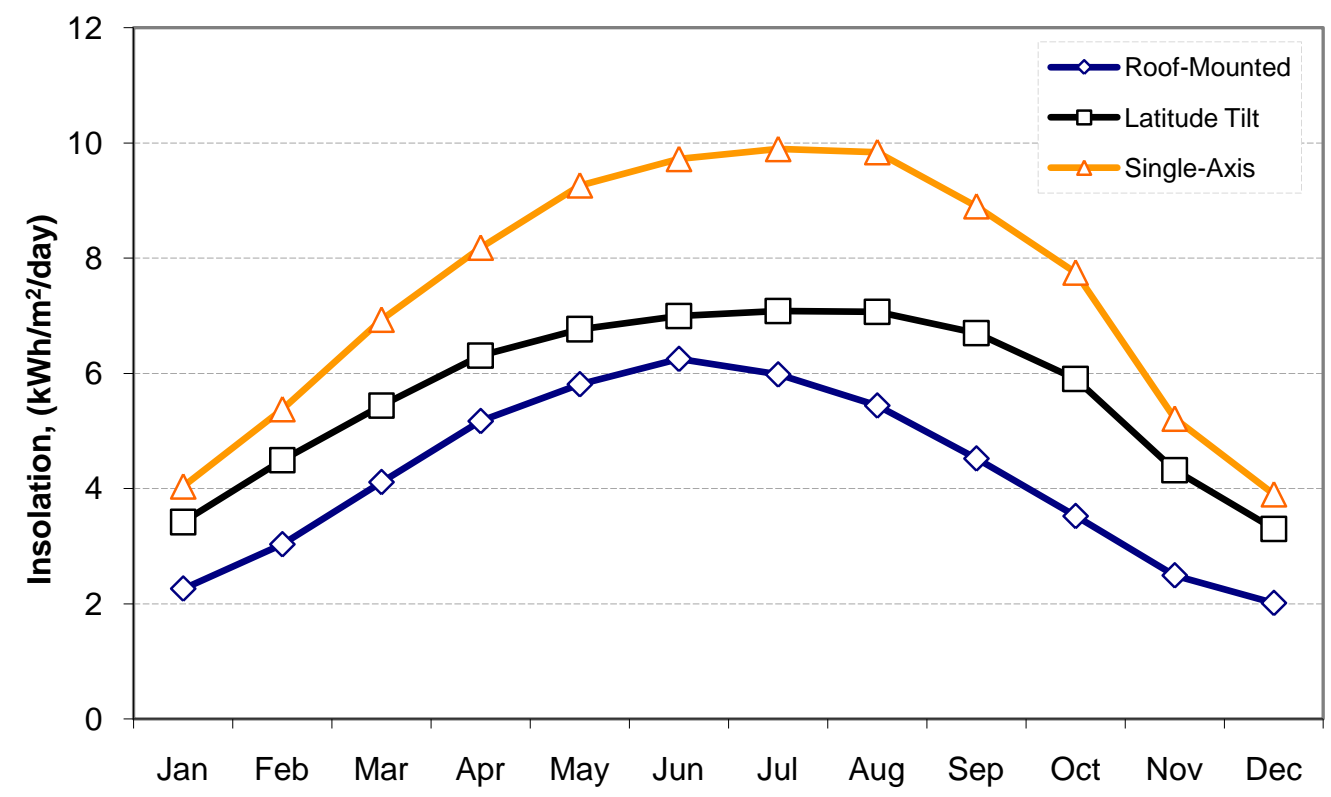

Figure 1: Annual Solar Resource

\section{Site Utility Details}

Pacific Gas and Electricity (PG\&E) is the electrical utility for Fort Hunter Liggett. In FY 2010, PG\&E sold the site 41,600 MMBtus of electricity at a cost of \$1,461,000 and at an annual average blended unit cost of \$35/MMBtu, or $11.97 \notin / \mathrm{kWh}$. 
PG\&E is a regulated California utility that must satisfy the state's renewable portfolio standard (RPS) mandates. PG\&E owns the utility line up to the base's main metering point, which is located in the main cantonment near Building 79. With a few exceptions, the remaining lines are owned by Fort Hunter Liggett. Because of the Fort's relatively small size and load, the existing distribution system mostly uses $12-\mathrm{kV}$ lines. The existing infrastructure varies in quality and depending on the location of the proposed PV array, several lines and poles may need to be repaired.

Most utilities prefer that no more than $10 \%$ of the peak distribution feeder load be supplied by a distributed generation source such as wind or solar. In the case of Fort Hunter Liggett, the Fort consumes almost the entire distribution feeder load. Adding a 1-MW PV array to a peak load of 2.6-MW could be problematic given typical utility interconnection standards. Nevertheless, the state's net metering laws allow the site to install up to 1-MW of on-site power. However, careful coordination with PG\&E will be required to ensure proper integration into the local grid. PG\&E, the site's electrical utility, is already aware of the plans to construct a PV array. If Fort Hunter Liggett is interested in establishing an interconnect and selling power back onto the grid, California's Rule 21 requires that an initial review process is completed for systems greater than $10 \mathrm{~kW}$.

Lastly, the site wishes to maintain ownership over the array and the renewable energy credits associated with the electricity it produces. By maintaining ownership and locating the facility on government land, the site will be able to double count the renewable energy production towards the EPAct 2005 goals. The site also wishes to have a web-based monitoring tool to access and display array power and energy production.

\section{Site Environmental Concerns}

Fort Hunter Liggett is home to two threatened species: the Purple Amole, a short, flowering plant, and the Arroyo Toad, a small toad native to Southern California. Areas known to have the Purple Amole or that are Arroyo Toad breeding grounds will not be suitable for PV array development. The sensitive areas map, see Figure 2, displays areas around the cantonment that have these species present.

Flooding and, more commonly, pooling that results from soil saturation and a shallow water table is common during the spring rains. This pooling could make array access challenging and cause the foundation of an array to become unstable. These phenomena are mostly confined to the western area of the cantonment, west of Mission Road. The land within the cantonment generally slopes upwards towards the north, and the pooling becomes especially prominent south of Del Venturi Road.

Fort Hunter Liggett is also home to two culturally sensitive areas. The first is the historic Spanish Mission of San Antonio located north of the cantonment area. The second is a historic hunting lodge, called The Hacienda, which is located within the cantonment area at the intersection of Sulphur Springs Road and Infantry Road. There is significant sensitivity to construction around these areas and there is a strong interest in preserving the view corridors of the valley for both of these structures because of their historic status. 
The areas around Fort Hunter Liggett experience frequent wildfires. Significant quantities of dust and soot are produced during these events. At times, the dust and soot are severe enough to cause problems to the electrical transmission system. In light of this observation, a PV array may also experience decreased electrical output because of dust and soot accumulation on the modules. It may be necessary to maintain a relatively active cleaning regimen during the summer and fall when wildfires are relatively common.

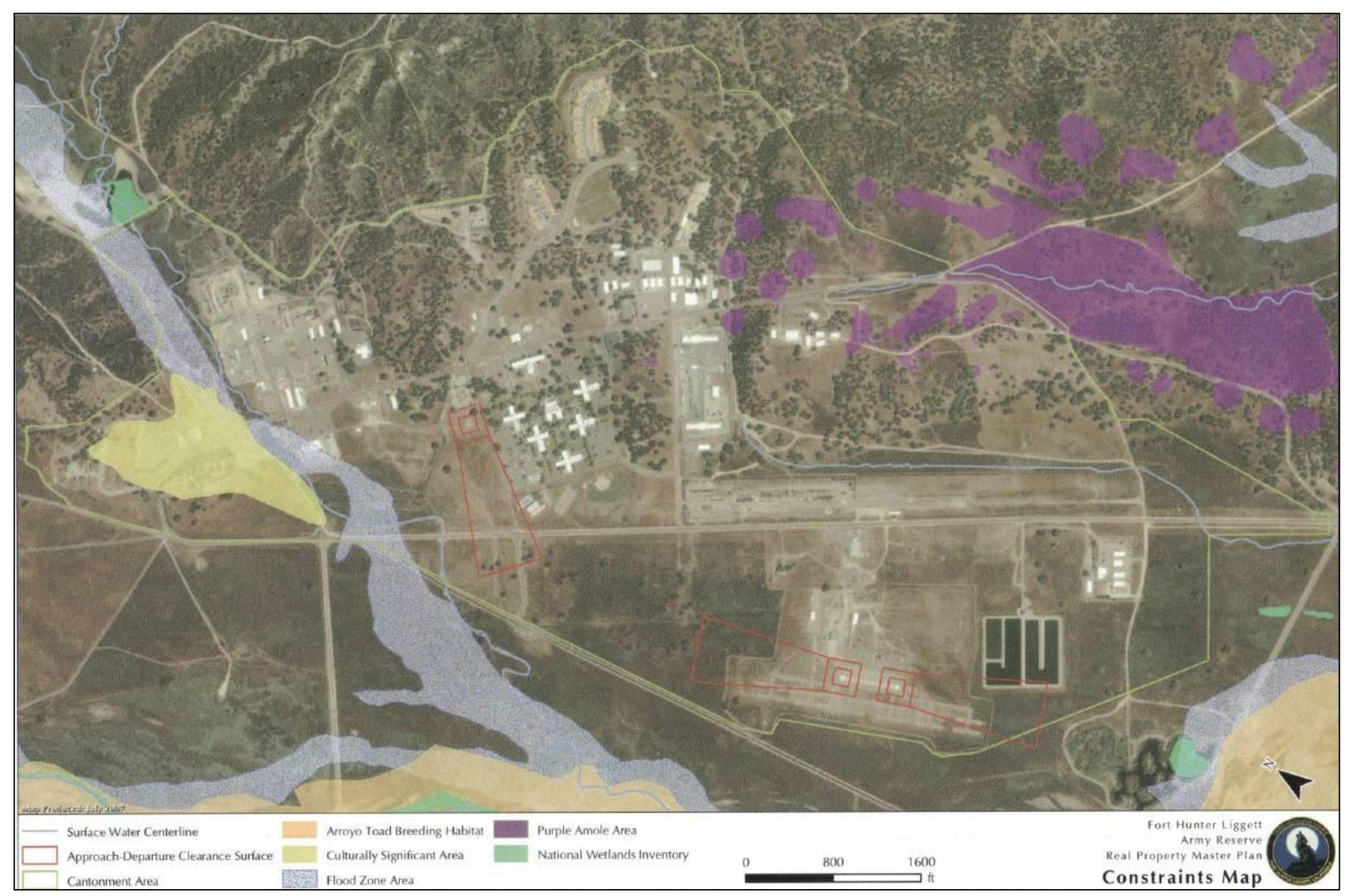

Figure 2: Sensitive Areas Map

\section{Proposed Array Locations}

Compared to most renewable energy technologies, PV arrays have a fair degree of siting flexibility. As previously mentioned, an array can be mounted on the ground or upon existing buildings and structures. A potential site needs to be free of any objects, such as trees or buildings, which may cast a shadow on the array. Also, the system will require an inverter to convert the DC output power into AC power. For projects $25-\mathrm{kW}$ or larger, it is common to use multiple inverters to optimize the system's efficiency as well as provide redundancy.

A typical 1-kW PV array may range in size from 8 to $9 \mathrm{~m}^{2}$; however, a larger array requires access space as well as spacing between the rows of panels to avoid self-shading, and will subsequently require a greater amount of space per installed $\mathrm{kW}$. For example, a $30-\mathrm{kW}$ array would likely require $550 \mathrm{~m}^{2}$, and a $100-\mathrm{kW}$ array may require nearly $2,000 \mathrm{~m}^{2}(0.5$ acres $)$, 
assuming that the PV array occupies $50 \%$ of the available space. Panels mounted on slanted roofs can usually be more tightly grouped because of a decrease in self-shading potential. Lastly, large arrays can produce considerable amounts of energy and require siting near existing high voltage power lines.

One of the primary goals of the study was to review possible sites for a 1-MW PV array. Despite having nearly 165,000 acres of land, Fort Hunter Liggett is constrained for space. Set deep in the coastal foothills, the cantonment area is located in the largest valley within the Fort's lands and is roughly rectangular in shape, with its principle axis roughly oriented along the NW-SE axis. To the east of the cantonment area is a series of steep hills and to the west is a floodplain and the San Antonio River, which typically runs dry during most of the year. Further west are a series of steep hills. Figure 3 displays these major geographical features via a topographical map of the cantonment area.

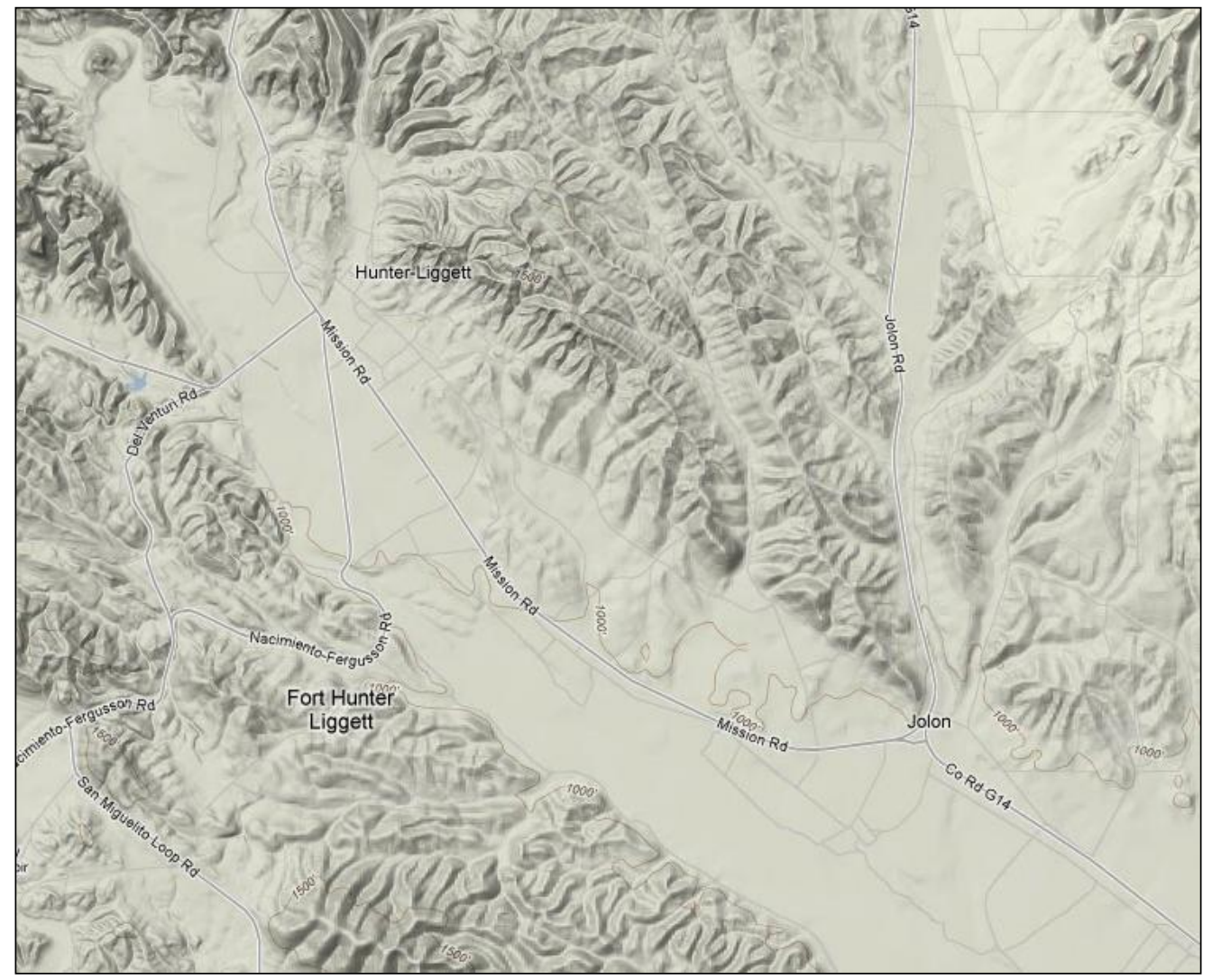

Figure 3: Cantonment Area Topography (Google 2010)

During the site visit, PNNL identified three primary areas that might be suitable for the proposed array:

1. The Primary Vehicle Parking Area,

2. The Northwest Field, and

3. The South Field.

Site 1: Primary Vehicle Parking Area 
Because of the space constraints present at Fort Hunter Liggett, the site was particularly interested in exploring a combination PV array and a vehicle parking shade structure. Fort Hunter Liggett has a large, 30-acre parking area used to store a wide variety of vehicles. At 30 acres, the existing lot is more than sufficient to house a 1-MW array assuming typical panel spacing distances. PV panels mounted on shading structures may be spaced more densely, but the uncovered throughways will result in unutilized space. Nevertheless, there should be sufficient space for a 1-MW array if it were mounted on shading structures. Site constraints include utility poles, streetlight poles, occasional relocatable trailers, and the wide variety of vehicle sizes. The distribution of vehicle sizes may be the largest challenge for this location if the parking structure strategy is pursued. Figure 4 identifies Site 1 . Note that the overhead image is several years old and that this entire lot is currently occupied

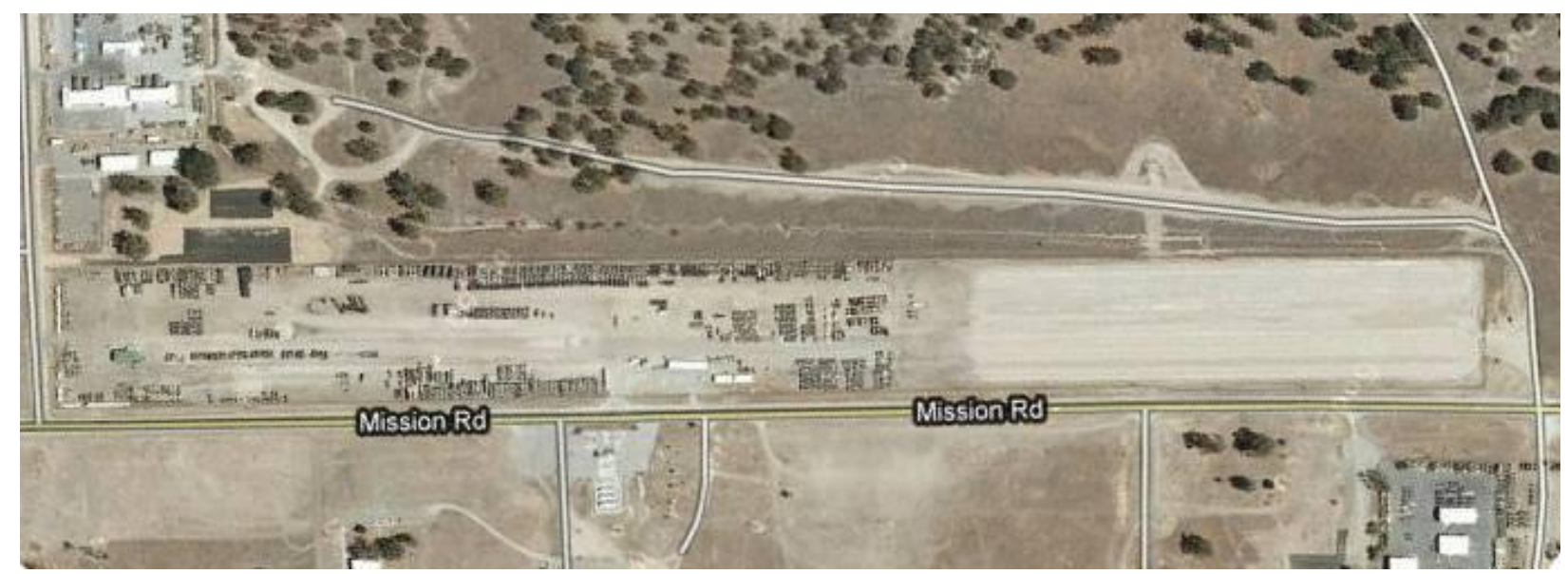

Figure 4: Primary Vehicle Parking Area (Google 2010)

\section{Site 2: Northwest Field}

A sizeable field northwest of the barracks is open. This area is approximately 30 acres in size and is generally flat. A small creek runs along the northwestern end of the location and bends southward along the western edge of the property until it crosses under Mission Road. The sensitive area map (see Figure 3) indicates that a portion of this land is a flood control area. The primary feeder from PG\&E also borders this property. Two different futures maps suggest that this area may be developed as an Operational Readiness Training Complex (ORTC) or as two moderately sized buildings with parking lots. With sufficient planning, this area may be developed to host the PV array and either of these potential projects. A major advantage of this site is that it is clear and would be easy to develop given the minimal need to grade the land, remove vegetation, and create access corridors for workers and infrastructure. Figure 5 identifies Site 2. 


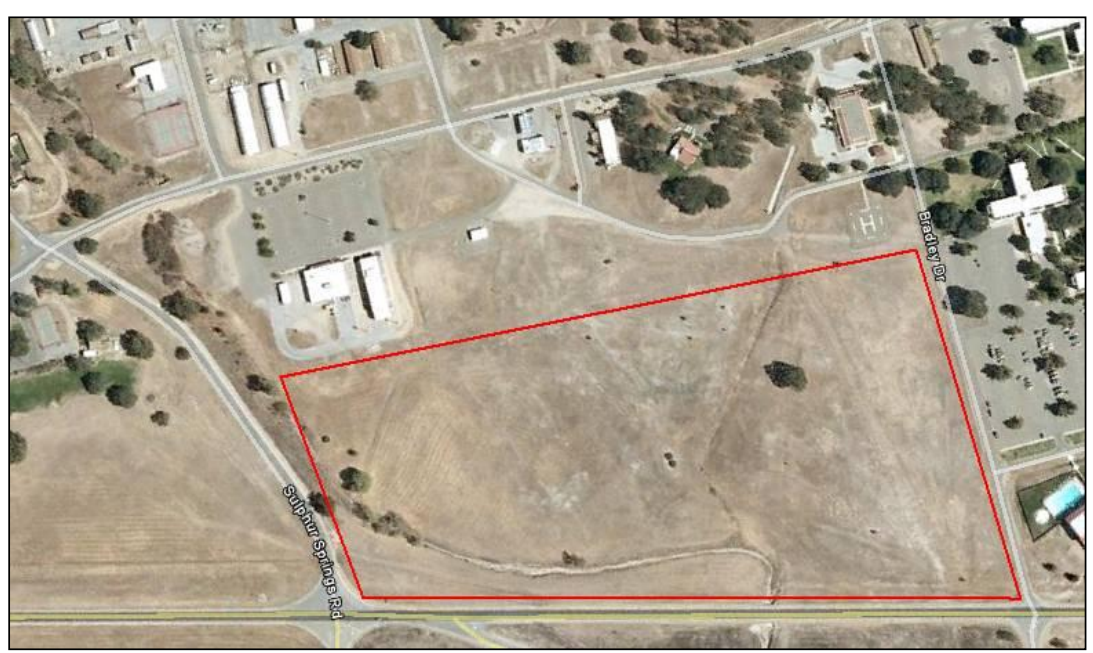

Figure 5: Northwest Field (Google 2010)

Site 3: South Field

The field at the corner of Sulphur Springs and Mission Road is an ideal location for a PV array. West of The Hacienda (the structure at the top of Figure 6) and just west of Mission Road is a large parcel of land over 15 acres in size. Lands west of Mission Road frequently experience standing water accumulation during the spring rains. While this potentially disqualifies many areas for future development, lands northwest of Sulphur Springs/Del Venturi Road are at a slightly higher elevation, appear to have minimal standing water issues, and are outside of the floodplain. In addition, this area is close to the primary feeder and other high voltage lines. A disadvantage to this location is that it is in the view corridor of the Hacienda, which is protected because of the building's historic status. 


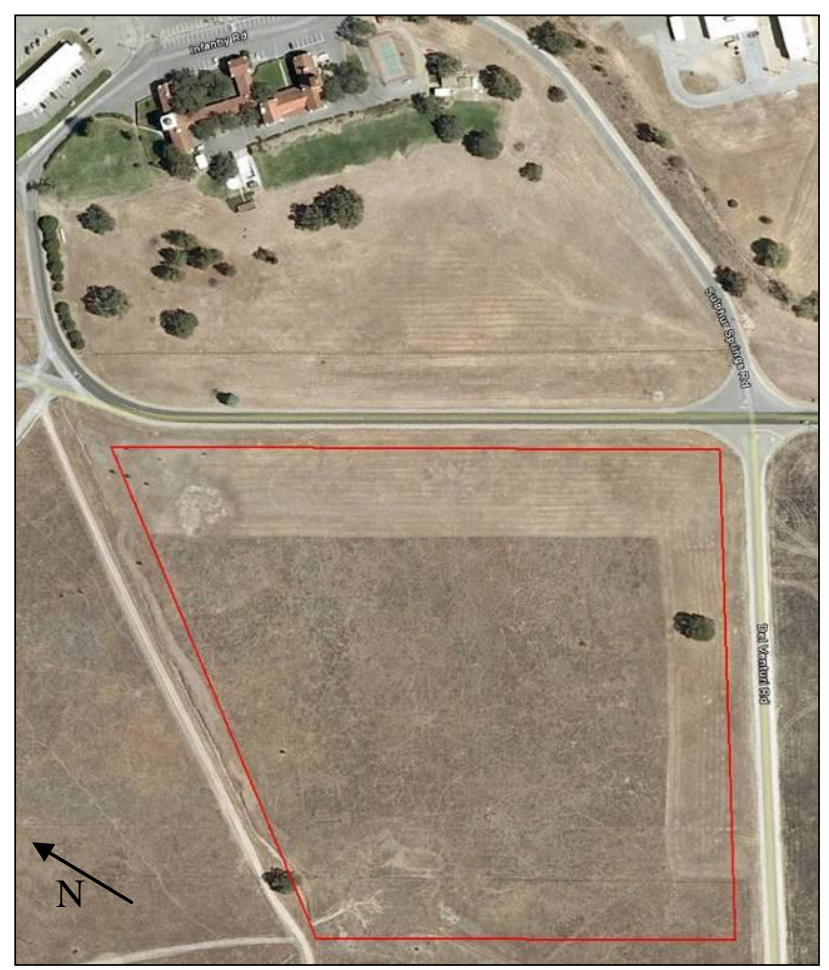

Figure 6: South Field (Google 2010)

Other Areas:

A handful of other areas were briefly considered for array siting.

An area immediately north of the helipads has been identified as a "solar field" development area on one of the futures maps. This area is close to the primary transmission lines, is open, and does not conflict with any sensitive areas. However, this area frequently experiences water pooling. In addition, there are concerns about siting PV arrays in close proximity to airfields because of reflection and glare.

Another area west of the small reservoir behind an earthen dam was also identified as a potential array location. However, the space restriction, uneven land, and potential shading from the nearby hills that border the site to the north, east, and south limit this area's potential for PV siting.

A handful of areas outside of the cantonment were also visited. Fort Hunter Liggett hosts many training exercises in areas of the post beyond the reach of the transmission lines. These areas often use small capacity generators for power, which produce expensive electricity. However, these areas are not consistently in use, and it is impossible to predict the training patterns in light of the 20-year lifetime of the array. Consequently, the PV array may not be fully utilized if it is sited in these training lands. Other possible sites include areas southeast of the main cantonment area. However, this area includes the Fort's active airfield and concerns have been expressed about constructing a PV array around this area because of training interference. Areas northeast of the runway are currently undeveloped, but are also relatively woody and slightly hilly. Areas further south are outside the main gate. 
Appendix A provides additional details about the proposed sites.

\section{Proposed Photovoltaic Technologies to Consider}

PNNL was tasked with providing guidance concerning the development of the on-site array including PV module section. Specifically, the site requested an appraisal of the existing module technology and was particularly interested in the environmental attributes of the various technologies.

Although PNNL cannot endorse specific manufacturers, PNNL was able to provide the site a summary of the dominant technologies that discuss their strengths and weaknesses. The summary of the technologies included the main types of silicon PV modules (i.e., polycrystalline $\mathrm{Si}$, monocrystalline $\mathrm{Si}$, amorphous thin film $\mathrm{Si}$ ), cadmium telluride thin film (CdTe) cells, organic/polymeric cells, and copper indium gallium selenide (CIGS) thin film cells.

In addition to a summary of the modules, the site requested feedback on the environmental attributes of the technologies. With the exception of organic modules, the module technologies are semiconductors manufactured with similar and comparable techniques. The most notable environmental concern surrounds the fabrication, use, and disposal of CdTe cells. Cadmium is a heavy metal with known human health impacts. Although the quantity of $\mathrm{Cd}$ in these cells is minimal, the mere presence of this compound can be a cause of concern. Moreover, special care must be taken during the disposal process of these modules to assure containment of the cadmium. Several manufacturers of CdTe modules have recycling programs for their modules. However, because modules have a lifetime of 20 years or more, these recycling programs may not be available during array deconstruction. Copper indium gallium selenide (CIGS) cells also have similar concerns pertaining to its constituent compounds.

\section{Development Challenges}

The primary challenges observed for PV development pertains to array siting and mitigation of the known environmental issues. Site 1 lacks many of the environmental issues because it is already developed and environmental issues have long since been mitigated. However, the parking area is in constant use and construction of any shade and PV support structure must be coordinated with mission operations to avoid conflicts. In addition, the need to lay a concrete slab, the shading structure, and the array will consume funds that could otherwise be used to construct a larger array.

Sites 2 and 3 provide suitable open space with minimal construction or logistical issues. However, they will require additional environmental reviews. Moreover, Site 3, which may be the most flexible and spacious, is in the view corridor of the Hacienda, which may pose a challenge since the view corridor is protected because of the building's historic status.

Currently, Site 1 is the most favorable because this land is already developed and vehicles could benefit from a shading structure. Environmental issues would be minimal and access to overhead lines and the site's substation is straightforward. 


\section{Conclusions}

Fort Hunter Liggett has several factors that allow it to be a suitable candidate for a solar PV array. The moderate solar resource, the relatively high cost of the displaced electricity, a proactive public works staff, and an engaged utility synergistically enable Fort Hunter Liggett to pursue solar PV. While on site, PNNL identified several possible array sites all within close proximity of the existing overhead lines and the primary substations. Each of these sites has a unique challenge, and the site will have to conduct a net benefit analysis to decide which site is the most suitable. However, Site 1 will likely be the most practical given the lack of substantial environmental review and mitigation necessary to construct the array.

Regarding module selection, if Fort Hunter Liggett desires to pursue the most environmentally benign cell module, the site should consider silicon modules. However, nearly all modules have approximately equivalent environmental impact.

\section{List of Deliverables}

1. Summary of potential array siting locations, maps, and identification of possible challenges,

2. Summary of PV technologies, price trends, and site specific considerations, and

3. A site visit and subsequent support.

\section{Sources of Information}

Google. 2010. Google Maps. Accessed May 2010 at http://maps.google.com

Minister of Natural Resources Canada. 2008. RETScreen Clean Energy Project Analysis Software. RETScreen International Clean Energy Decision Support Centre, Minister of Natural Resources Canada, Ottawa, Ontario, Canada. Accessed May 2010 at http://www.retscreen.net (last updated March 3, 2010).

NASA - National Aeronautics and Space Administration's Langley Research Center and Atmosphere Science Data Center. 2010. Surface Meteorology and Solar Energy. Accessed May 2010 at http://eosweb.larc.nasa.gov/sse (last updated May 4, 2010). 
Appendix A

Detailed Description of Potential Array Locations 



\section{Appendix A: Detailed Description of Potential Array Locations}

One of the primary goals of the site visit was to review possible sites for a 1-MW PV array. A variety of areas were identified as potentially suitable for a PV array. A number of the locations were identified by site personnel and the remaining were selected by PNNL.

\section{Area 1:}

Because of the space constraints present at Fort Hunter Liggett, the site was particularly interested in exploring a combination PV array and a vehicle parking shade structure. Fort Hunter Liggett has a large parking area that is used to store a wide variety of vehicles (see the following series of photographs at the end of this section for a sample of vehicles at this site). The smallest vehicle are humvees, while the largest are tankers and flatbed vehicles with other vehicles/equipment stacked on the bed. This parking lot (Figure A-1) is approximately 30 acres in size. There are plans to expand this parking area (indicated in red in Figure A-1) to the east by about 75 meters, which will add another 30 acres to the existing lot. The primary feeder from PG\&E borders this property.

At 30 acres, the existing lot is more than sufficient to house a 1-MW array assuming typical panel spacing distances. PV panels mounted on shading structures may be spaced more densely, but the uncovered throughways will result in unutilized space. Nevertheless, there should be sufficient space for a 1-MW array.

Site constraints include utility poles (see Figure A-2 and A-3), streetlight poles, occasional relocatable trailers, and the wide variety of vehicle sizes. The distribution of vehicle sizes may be the largest challenge for this location if the parking structure strategy is pursued (see Figure A4). However, given the large number of humvees present and that humvees are the shortest vehicle at this lot, a parking structure sized to accommodate just this vehicle type could be considered.

A major challenge to developing this site with the combination of a PV array and a vehicle parking shade structure is time. This approach will take longer to design and construct. Also, it will pose a logistical challenge because portions of this yard will need to continue to be in use during the time of construction. As a result, it may be advisable to consider building the initial 1MW on unused lands and to consider the shading structure approach for future array expansions. Another approach is to build the shading structures on the undeveloped lands (lands within the red box) that will eventually be converted into additional vehicle storage space. This will avoid logistical conflicts with the existing storage area during the construction phase. However, this level of coordination may not be able to occur within the remaining time. 


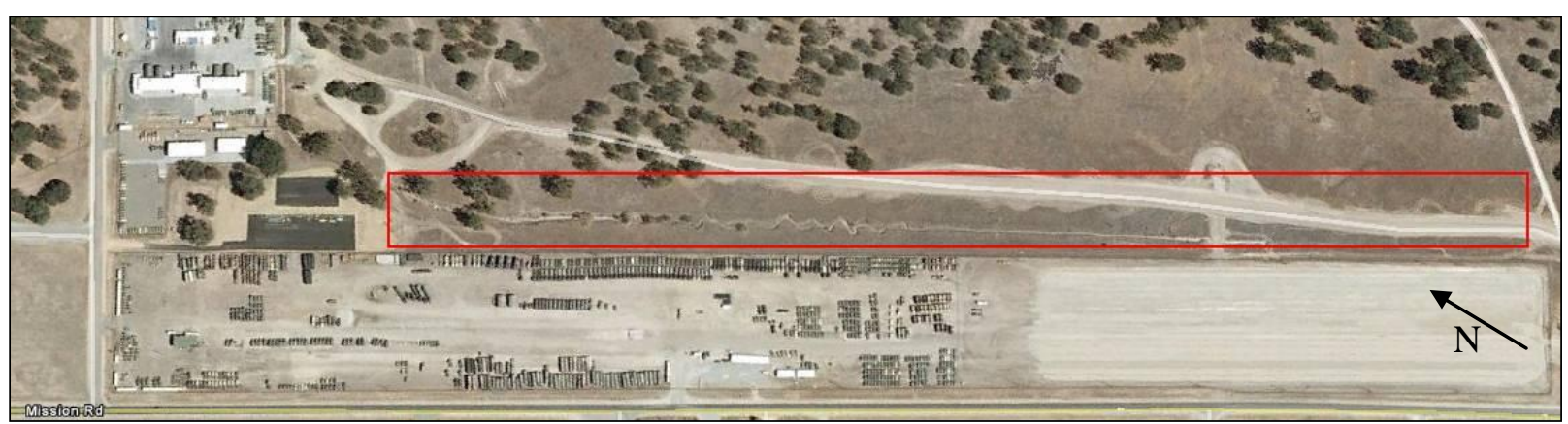

Figure A-1: Vehicle Storage Area (the area in red indicates future expansion) (Google 2010)

Note that the overhead image is several years old and that this entire lot is now occupied.

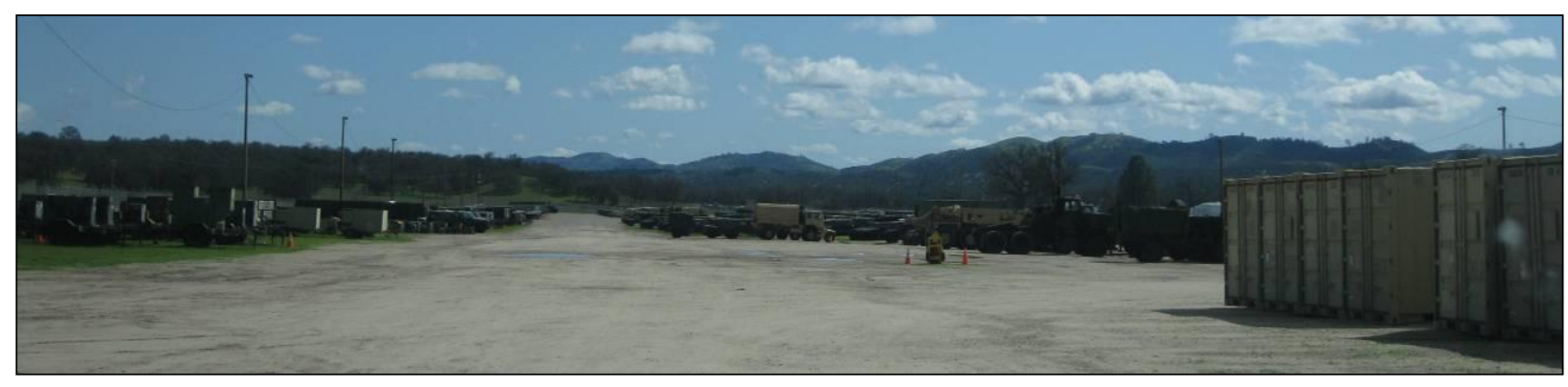

Figure A-2: Wide Angle Shot of the Vehicle Storage Area

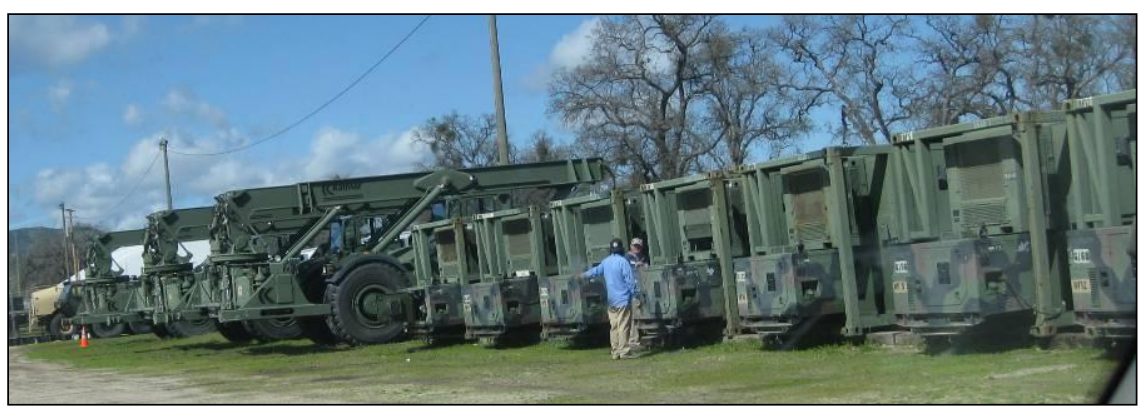

Figure A-3: Large Vehicles Stored at the Vehicle Storage Area

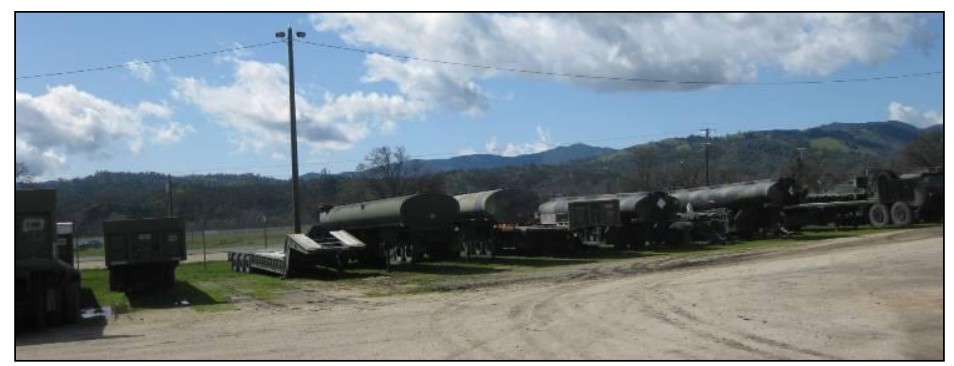

Figure A-4: Fuel Tankers in the Vehicle Storage Area

\section{Area 2:}

A small area to the east of the primary vehicle storage area is also a potential site for a combination of a PV array and a vehicle parking shade structure. This area is smaller than the 
first area and has a greater number of obstructions such as streetlights and buildings. The area is approximately 5 acres in size, which is insufficient for an array given the constraints of the location. Figure A-5 identifies this area.

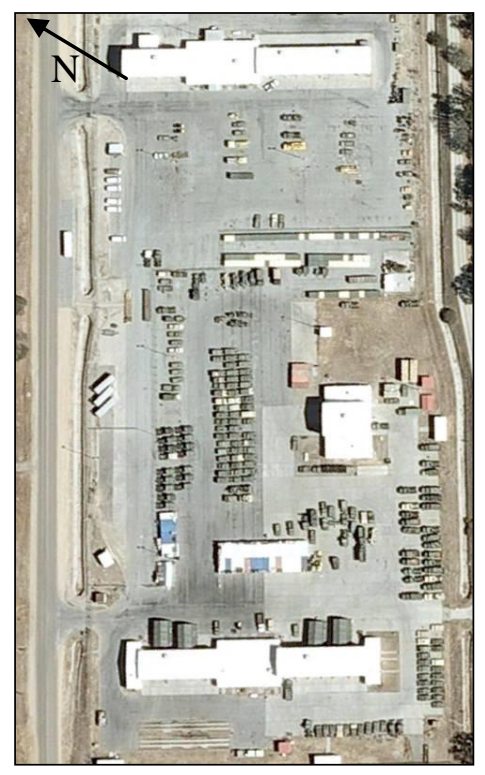

Figure A-5: Vehicle Storage Area (Google 2010)

\section{Area 3:}

A sizeable field northwest of the barracks is open (see Figures A-6 to A-8). This area is approximately 30 acres in size and is generally flat. A small creek runs along the northwestern end of the location and bends southward along the western edge of the property until it crosses under Mission Road. The sensitive area map (see Figure 3) indicates that a portion of this land is a flood control area. The primary feeder from PG\&E borders this property. Two different futures maps suggest that this area may be developed as an operational readiness training complex or as two moderately sized buildings with parking lots. With sufficient planning, this area may be developed to host the PV array and either of these potential projects. A major advantage of this site is that it is currently clear and would be easy to develop given the minimal need to grade the land, remove vegetation, and create access corridors for workers and infrastructure.

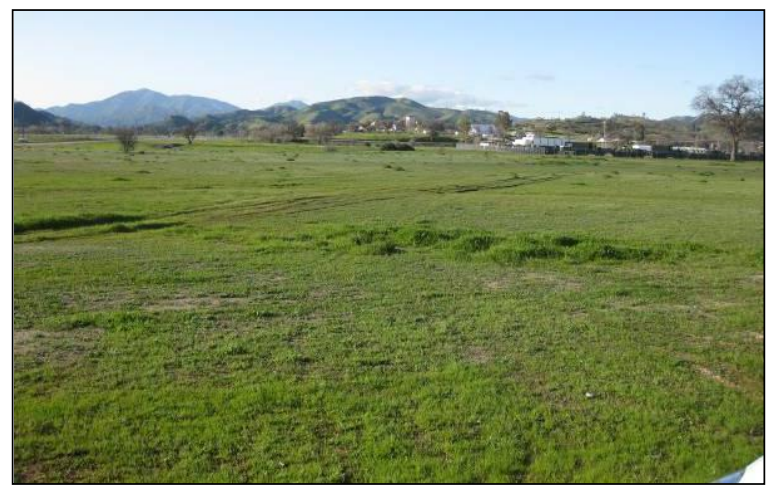

Figure A-6: Open Field Facing Northwest 


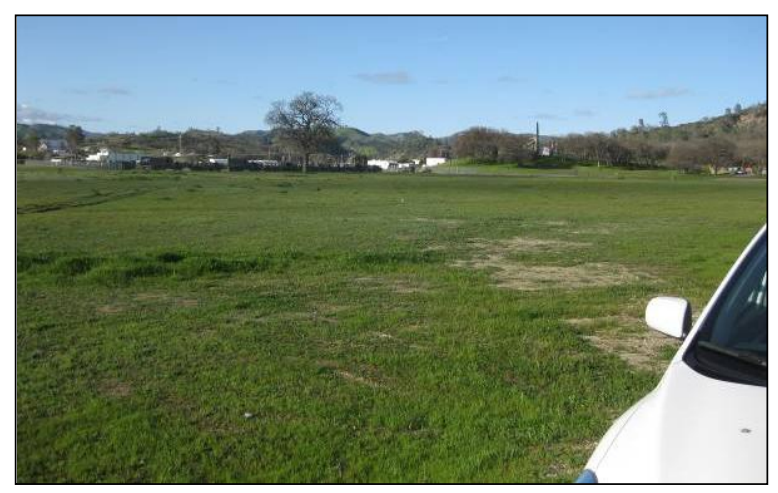

Figure A-7: Open Field Facing North

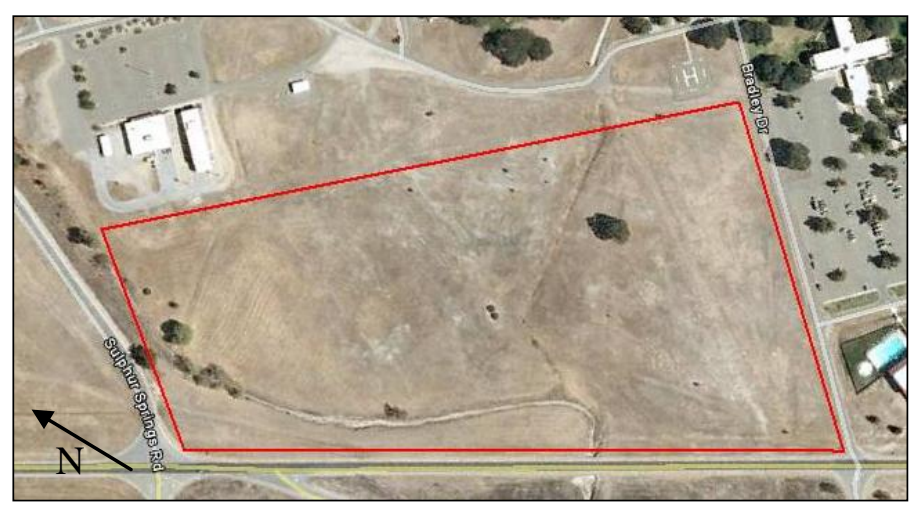

Figure A-8: Open Field (Google 2010)

\section{Area 4:}

A large area approximately 17 acres in size in the northwestern portion of the cantonment is dominated by the Department of Public Works (DPW) vehicle storage lots, vehicle maintenance areas, and several small shops. This area is currently cluttered with vehicles, construction materials/debris, and other various objects. However, it was expressed by the site that this area might be relatively straightforward to convert into a PV power plant given the difficultly of landuse conversion at other potential sites. A challenge of this site is that it is currently occupied and would not be easy to develop given the need to grade the land, remove vegetation, and create access corridors for workers and infrastructure. Figure A-9 identifies this area. 


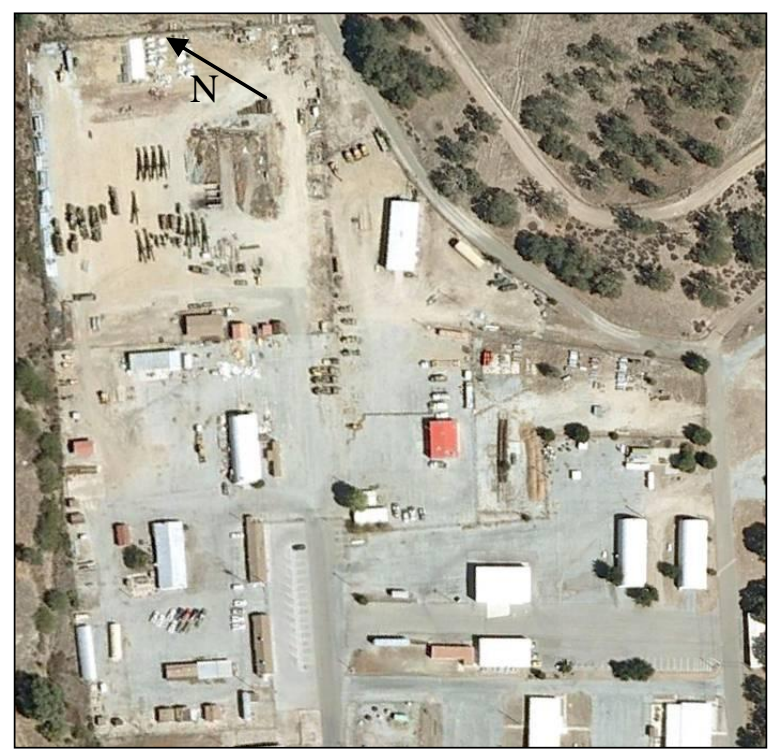

Figure A-9: Western Portion of the Cantonment (Google 2010)

\section{Area 5:}

There is an ideal area for a PV array at the corner of Sulphur Springs and Mission Road. West of The Hacienda and just west of Mission Road is a large parcel of land over 15 acres in size. Lands west of Mission Road frequently experience standing water accumulation during the spring rains. While this potentially disqualifies many areas for future development, lands northwest of Sulphur Springs/Del Venturi Road are at a slightly higher elevation, appear to have minimal standing water issues, and are outside of the floodplain. In addition, this area is very close to the primary feeder and other high voltage lines. A major advantage of this site is that it is currently clear and would be easy to develop given the minimal need to grade the land, remove vegetation, and create access corridors for workers and infrastructure. A disadvantage to this location is that it is in the view corridor of The Hacienda. However, if Fort Hunter Liggett continues to grow, this land may eventually need to be developed. Figure A-10 identifies this area. 


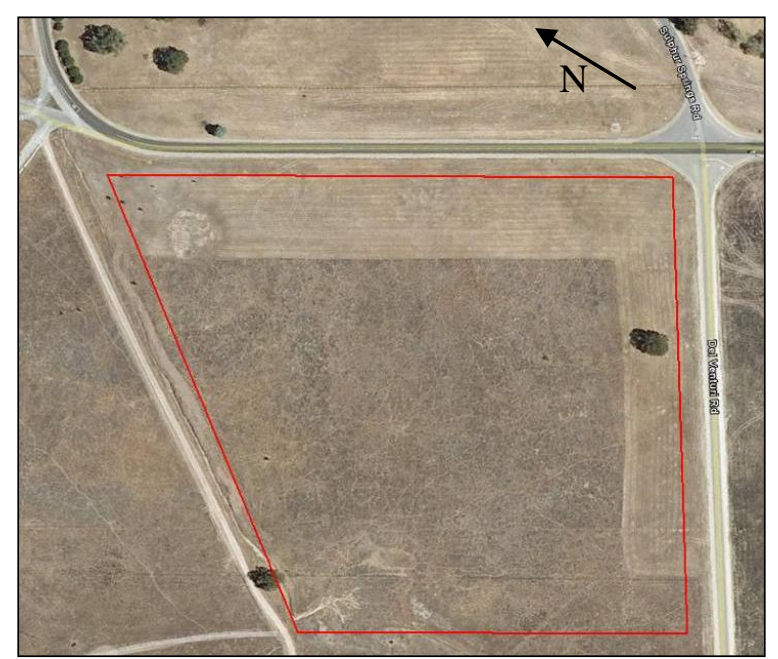

Figure A-10: Open Area SW of Sulphur Springs \& Del Venturi (Google 2010) 
Appendix B

Common PV Module Technologies 



\section{Appendix B: Common PV Module Technologies}

There are four common photovoltaic materials in use in commercial products: silicon, cadmium telluride (CdTe), polymeric, and copper indium gallium selenide (CIGS). For each of these material classes, there are often several variations and subclasses.

There are several less common material systems and fabrication methods. These include multijunction cells, dye-sensitized solar cells or Gratzel cells, and quantum cells (e.g., quantum dots). These cells are either pre-commercial or exceptionally expensive and are not likely candidates for PV cells at Fort Hunter Liggett.

Concentrating PV (CPV) is also becoming more common. CPV systems use mirrors and lenses to concentrate sunlight onto a PV module. Although this technology is promising, it is still generally considered to be pre-commercial.

\section{1: Silicon PV}

Silicon is the most common photovoltaic material used in commercial PV systems. As a material system, it is well understood and has a good balance of performance and cost.

\section{A: Polycrystalline Silicon}

Polycrystalline silicon solar cells are one of the most common, if not the most common, types of solar cell. These commercial polycrystalline cells have efficiencies in the range of 8 to $16 \%$. These cells are usually ridged, and the modules are rectangular. Because of simple fabrication techniques and feedstock flexibility, these cells tend to be more moderately priced compared to single crystal silicon solar cells.

Well-known manufacturers of polycrystalline silicon include BP Solar, Kyocera, Q-Cells, Shell, and Yingli Solar. Please keep in mind that we are by no means endorsing specific items or manufacturers, nor do we imply that this list is all-inclusive.

\section{B: Monocrystalline Silicon}

Monocrystalline silicon solar cells are another common type of solar cell. These cells have efficiencies in the range of 8 to $20 \%$. These cells are also ridged, and the modules are rectangular. Traditionally, monocrystalline silicon solar cells were considerably more expensive than their polycrystalline counterpart. However, the downward price trend of PV materials in the last few years has decreased the absolute cost difference between these two options, which has made monocrystalline more cost effective when compared to polycrystalline.

Well-known manufacturers of monocrystalline silicon solar cells include BP Solar, Q-Cells, Sanyo, Sharp, and Sunpower. Please keep in mind that we are by no means endorsing specific items or manufacturers, nor do we imply that this list is all-inclusive.

\section{C: Amorphous Silicon}

Historically, amorphous silicon (a-Si) has been the most cost competitive silicon option amongst silicon solar cells because of their low fabrication cost. However, these systems have also suffered from relatively low efficiencies, which are typically in the range of 2 to $8 \%$. Ten years ago, when the module price was a much larger fraction of the net PV array price, a-Si 
technologies were more popular. However, as module prices for other systems have fallen, this technology has become slightly less popular. A-Si solar cells are sometimes referred to as thin film cells because of their fabrication techniques.

The U.S. company Unisolar is an industry leader of a-Si manufacturing and produces flexible PV membranes that are suitable as a roofing replacement material. Other manufacturers include BP Solar and Q-Cells. Please keep in mind that we are by no means endorsing specific items or manufacturers, nor do we imply that this list is all-inclusive.

\section{2: Cadmium Telluride (CdTe) PV}

Cadmium telluride solar cells are classified as a "thin film" solar cell due to the minimal amount of photovoltaic material needed to manufacture a module. Because of the minimal amount of material needed during manufacturing and the avoidance of expensive, semiconductor grade silicon, CdTe is relatively inexpensive compared to Si cells. Typical commercial CdTe PV module efficiencies range from 8 to $12 \%$.

One of the larger concerns of CdTe solar cells is the presence of cadmium, a heavy metal known to have adverse health and environmental affects. Cadmium is common in many other products, is most notable as a battery component in nickel-cadmium batteries, and is present in many fertilizers, a byproduct of metal production, and from natural sources in the environment. In typical CdTe PV modules, the concentration of $\mathrm{Cd}$ is about 70 grams per $\mathrm{kW}$. Although the concentration of $\mathrm{Cd}$ in CdTe solar cells is relatively low, it continues to be an area of concern. Some CdTe PV fabrication companies do offer recycling programs. The only caveat to participating in a recycling program is that the program must still be in existence at the end of the array's lifetime some 20 to 30 years after array construction. Third-party recyclers may exist in the future, but no major recycler currently exists.

The U.S. company First Solar is the largest manufacturer of CdTe PV modules. They are active in assisting large organizations and state/Federal installations with designing and constructing large PV arrays. Other common manufacturers include Primestar Solar, AVA Solar, Solar Fields, Canrom, and others. Please keep in mind that we are by no means endorsing specific items or manufacturers, nor do we imply that this list is all-inclusive.

\section{3: Polymeric}

Polymeric (also known as organic) solar cells are a relatively new option in the commercial PV market. These cells promise very low fabrication costs and flexible substrates. Typical commercial cell efficiencies rage from 4 to $8 \%$. Although polymeric solar cells are becoming common in a handful of niche applications (e.g., PV integrated into computer bags), they are not used in large-scale PV arrays and should not be considered at Fort Hunter Liggett.

\section{4: Copper indium gallium selenide (CIGS)}

CIGS PV cells are also classified as a thin film PV technology. Like CdTe cells, the minimal amounts of material needed during manufacturing and the relatively low cost of the constituent materials (with the exception on indium) allows for relatively low cost module fabrication. Indium is a valuable raw material for many electro-optic applications and tends to influence price trends in CIGS cells. Typical commercial CIGS cell efficiencies range from 10 to $15 \%$. 
CIGS cells contain selenium, which is a known to be toxic in large doses. However, CIGS solar cells contain only traces amounts of selenium, and CIGS solar cells are not regarded as a major toxicity threat.

Well-known manufacturers of CIGS include Nanosolar, Global Solar, Heliovolt, Dow Chemicals, and others. Please keep in mind that we are by no means endorsing specific items or manufacturers, nor do we imply that this list is all-inclusive. 
B-4 


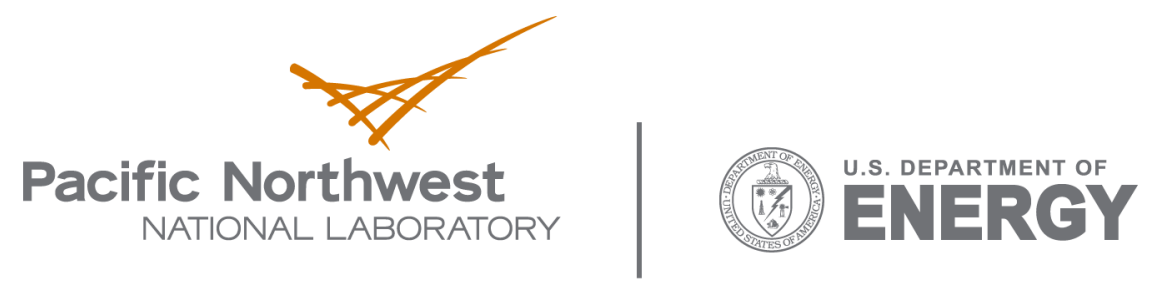

902 Battelle Boulevard

P.O. Box 999

Richland, WA 99352

1-888-375-PNNL (7665)

www.pnl.gov 